\title{
REALITAS PROFETIK DALAM NOVEL KETIKA CINTA BERTASBIH KARYA HABIBURRAHMAN EL-SHIRAZY
}

\author{
Anwar Efendi \\ Fakultas Bahasa dan Seni Universitas Negeri Yogyakarta \\ email: efendianwar@ymail.com
}

\begin{abstract}
Abstrak
Penelitian ini bertujuan untuk mendeskripsikan realitas profetik dalam novel Ketika Cinta Bertasbih karya Habiburrahaman El-Shirazy. Penelitian ini menggunakan pendekatan strukturalisme-dinamik (semiotik) dan analisis data dilakukan dengan teknik analisis isi. Hasil penelitian sebagai berikut. Pertama, realitas profetik pada aspek humanisasi tampak pada kehadiran sosok tokoh (manusia) yang telah terjebak pada pusaran modernitas kehidupan. Kedua, realitas profetik pada aspek liberasi berkaitan dengan relasi laki-laki dan perempuan dalam perspektif individu dan sosial. Ketiga, realitas profetik pada aspek transendensi berkaitan dengan kesadaran ketuhanan dan kerinduan pada kehidupan yang abadi.
\end{abstract}

Kata kunci: profetik, humanisasi, dehumanisasi, liberasi, dan transendensi

\section{THE PROPHETIC REALITY IN THE NOVEL KETIKA CINTA BERTASBIH BY HABIBURRAHMAN EL-SHIRAZY}

\begin{abstract}
This study aims to describe the prophetic reality in Ketika Cinta Bertasbih, a novel by Habiburrahaman El-Shirazy. It employed a structural-dynamic (semiotic) approach and the data were analyzed using content analysis. The results are as follows. First, the prophetic reality in the humanization aspect appears in the presence of a human being figure trapped in the vortex of life modernity. Second, the prophetic reality in the liberation aspect is related to the relation of men and women in individual and social perspectives. Third, the prophetic reality in the transcendence aspect is related to the awareness of God and longing for eternal life.
\end{abstract}

Keywords: prophetic reality, humanization, dehumanization, liberation, transcendence

\section{PENDAHULUAN}

Persoalan zaman dan kemasyarakatan dari kurun waktu tertentu berpengaruh pada pemilihan tema-tema yang diungkapkan para sastrawan dalam karyakaryanya. Pergeseran persoalan zaman dan persoalan kemasyarakan akan menyebabkan pergeseran pemilihan tema.

Sejak paruh terakhir dasawarsa 1990an, khazanah sastra Indonesia disemaraki oleh kehadiran fiksi Islami. Fiksi bernafaskan Islam tersebut menawarkan semacam "wacana baru" sebagai wacana sastra atlternatif bagi perkembangan sastra In- donesia mutakhir. Tradisi penulisan fiksi Islmi tersebut selanjutnya berkembang sangat marak, terutama sejak awal dasarwarsa 2000-an sampai saat ini (Herfanda, 2007).

Pada awalnya, tradisi fiksi Islami tampak sebagai upaya untuk membangun ruang alternatif bagi para penulis Muslim yang meyakini bahwa menulis adalah bagian dari upaya penyebaran nilai-nilai Islam. Para penulis tersebut berkeyakinan bahwa penyebaran karya sastra adalah bagian dari upaya pencerahan nurani masyarakat, sekaligus sebagai upaya me- 
nyediakan bacaan (fiksi) yang lebih sehat bagi masyarakat Islam terpelajar.

Aspek menarik yang perlu dicatat dalam perkembangan tradisi penulisan fiksi Islami yaitu fenomena munculnya tradisi fiksi Islami ternyata sebagai kelanjutan dari berkembangnya tradisi "fiksi sekuler" atau "fiksi seksual". Kehadiran fiksi Islami dianggap menawarkan "wacana sastra baru" di tengah kecenderungan tradIsi penulisan fiksi Indonesia yang makin sekuler, yang lebih mengedepankan wacana sastra seksual. Kehadiran fiksi sekuler atau fiski seksual ditandai denan munculnya Saman karya Ayu Utami, disusul novel Ode untuk Leopold Von Sacher Masoch karya Dinar Rahayu, dan cerpencerpen Djenar Maesa Ayu (Herfanda, 2007)

Ada kepercayaan yang kuat di kalangan penulis muslim bahwa nilai-nilai yang diyakini oleh kreator sebuah karya sastra sangat menentukan apakah kehadiran karya sastra itu bermakna positif atau sebaliknya destruktif bagi masyarakat. Dalam hal inilah kehadiran penulis-penulis muslim menemukan relevansinya. Dengan gerakan fiksi Islami itulah, kehadiran para penulis muslim dianggap mempunyai kedudukan penting untuk memberi warna yang lebih mencerahkan bagi dunia fiksi Indonesia.

Maraknya fiksi Islami belakangan ini memang menggembirakan. Hanya saja, ada sebuah tantangan besar yang perlu dipikirkan terkait dengan mutu atau kualitas dan nilai kesastraannya. Secara konseptual, keberadaan fiksi Islami hakikatnya menggabungkan dua "wilayah" besar, yakni wilayah sastra (seni) dan wilayah agama. Wilayah seni (sastra) berbeda dengan wilayah agama. Sastra atau seni pada umumnya bermain dalam tataran wilayah estetika, sedangkan agama berada pada tataran wilayah etika dan dogma. Pada sisi yang lain, agama (religi) - etika menciptakan pagar (norma-norma), sedangkan sastra - es- tetika selau berusaha membongkarnya (Mashuri, 2003). .

Tradisi penulisan fiksi Islami tidak dapat dilepaskan dari keberadaan Majalah cerpen Annida dan kemudian organisasi penulis Forum Lingkar Pena (FLP). Majalah khusus cerpen (remaja) tersebut menjadi pesemaian awal tradisi penulisan fiksi Islami di Indonesia. Sejalan dengan berkembanganya Majalah Annida itu terus bermunculan penulis-penulis muda yang merambah wilayah fiksi Islami. Para penulis itulah yang kemudian berhimpun membentuk suatu komunitas kreatif sebagai wadah pengembangan kreativitas, terutama dalam dunia penulisan. Dengan diprakarsai oleh Helvy Tiana Rosa, Asma Nadia, dan Maiomon Herawati, mereka berhimpun dan membentuk wadah para penulis yang diberi nama Forum Lingkar Pena (FLP).

Seiring dengan perjalanan waktu, komunitas Forum Lingkar Pena (FLP) semakin berkembang dan ikut mewarnai gairah penulisan sastra Indonesia. Secara organisatoris FLP mengembangkan sayapnya dengan membentuk kelompokkelompok FLP di berbagai daerah di Indonesia. Forum Lingkar Pena telah memunculkan beberapa nama yang dianggap produktif dalam penulisan sastra Indonesia. Nama-nama seperti Helvi Tiana Rosa, Gola Gong, Asma Nadia, Pipiet Senja, Tary, Zaenal Radar T, Amran AZ., M. Iran Hidayatullah, Novia Syahidah, dan Dilla Fitri Ali adalah sederet penulis di antara puluhan penulis yang ikut mewarnai penulisan fiksi Islami di tengah perkembangan sastra Indonesia.

Salah satu penulis fiksi Islami yang dianggap fenomenal adalah Habiburrahman El-Shirazy. Dia adalah salah sati aktivis FLP cabang Kairo yang menghasilkan novel best seller, yang berjudul Ayatayat Cinta. Sampai saat ini novel tersebut masih tercatat sebagai novel terlaris dan telah memasuki cetakan ke-20 serta terjual lebih dari 240 ribu eksemplar. Menurut 
Herfanda (2007), novel Ayat-ayat Cinta, merupakan puncak dari gerakan fiksi Islami yang berkembang selama ini. Hampir semua ciri utama fiksi Islami, mulai dari gaya romatisme sampai pendekatan yang sangat Islmai ada dalam novel tersebut

Setelah berhasil dengan novel Ayatayat Cinta, Habiburrahman kembali melahirkan novel Islami yang diberi judul Ketika Cinta Bertasbih. Tampaknya novel kedua ini juga akan mengikuti jejak novel Ayat-ayat Cinta. Salah satu penandanya yakni terhitung bulan kedua dari awal penerbitanya, saat ini sudah mengalami cetak ulang yang ke-3.

Salah satu penanda penting kehadiran fiksi Islami dalam perkembangan sastra Indonesia adalah adanya semangat profetik. Semangat profetik dalam karya sastra dipandang penting karena merupakan sentral bertemunya antara dimensi sosial dan dimensi transendental yang terdapat dalam karya sastra. Karya sastra tidak hanya mengacu pada dimensi sosial yang terdeteksi secara indrawi, tetapi juga dunia transendental yang mengacu kepada dunia yang lebih hakiki (Malay, 1988).

Segi penting dalam sastra profetik adalah tolok ukurnya yang hakiki, yaitu sumber penemuan jati diri manusia kembali dan penyebab tumbuhnya kemungkinan-kemungkinan transendetal. Oleh karena itu, karya sastra profetik tidak hanya mengacu ke bumi tetapi juga mengacu ke langit. Artinya, karya sastra profetik berusaha menampilkan persoalan hakiki yang menyangkut kebenaran. Sastra yang memiliki semangat profetik adalah sastra yang tampil untuk selalu mengingatkan manusia akan Tuhannya, kebaradaan manusia di hadapan Tuhan, dan kesanggupan manusia menerima petunjuk Tuhan (Hadi WM, 1986).

Dalam pandangan Kuntowijoyo (2006:20), penyebutan istilah profetik dapat dilacak dalam Al-Quran (3:110), "Kamu adalah umat terbaik yang dilahirkan untuk manusia, menyuruh kepada yang ma'ruf, dan mencegah kemungkaran, dan beriman kepada Allah". Setelah menyatakan keterlibatan manusia dalam sejarah (ukhrijat linnas), selanjutnya ayat itu berisi tiga hal, yaitu "amar ma'ruf (menyuruh kebaikan, humanisasi), nahi munkar (mencegah kejahatan, liberasi), dan tu'minuna billah (beriman kepada Tuhan, transendensi). Berdasarkan rujukan di atas, realitas profetik yang berisi tiga hal, yaitu humanisasi, liberasi, dan transendensi.

Humanisasi kita perlukan, sebab ada tanda-tanda bahwa masyarakat kita sedang menuju ke arah dehumanisasi. Dehumanisasi ialah objektivasi manusia (teknologis, ekonomis, budaya, massa, negara), agresivitas (kolektif, perorangan, kriminalitas), loneliness (privatisasi, individualisasi), dan spiritual alienation (keterasinga spiritual. Dalam dehumanisasi perilaku manusia lebih dikuasai bawah sadarnya daripada kesadarannya. Dehumanisasi telah menggerogoti masyarakat Indonesia yang tampak dalam beberapa hal, yakni (1) terbentuknya manusia mesin, (2) manusia dan masyarakat massa, dan (3) budaya massa (Kuntowijoyo (2006:23),

Liberasi adalah upaya pembebasan atau memerdekakan. Dalam konsep filsafat, pembebasan mengandung dua dimensi, yakni (1) bebas dari, dan (2) bebas untuk. Dimensi bebas dari merupakan upaya menuntut hak-hak semata. Sementara itu, bebas untuk lebih menyaran pada pemaknaan kreatif dan positif atas kebebasan yang dimiliki.

Ada liberasi dari kekuatan eksternal dan ada liberasi dari kekuatan internal. Pada prinsipnya, kedua kekuatan eksternal dan internal dapat dijadikan tema sastra. Liberasi kekuatan eksternal antara lain: (1) kolonialisme, (2) agresi oleh negara adikuasa kepada negara lemah, (3) kapitalisasi dunia yang menyerbu negara-negara ketiga lewat berbagai rekayasa ekonomi. Liberasi kekuatan internal, antara lain: (1) penindasan politik atas ke- 
bebasan seni, (2) penindasan negara atas rakyatnya, (3) ketidakadilan ekonomi, dan (4) ketidakadilan gender (Kuntowijoyo (2006:24), .

Kesadaran ketuhanan (transendensi, trancendere (Latin) 'melampaui") sudah banyak dalam sastra Indonesia dan disebut dengan sastra transendental atau sastra sufi. Transendensi sebenarnya tidak harus berarti kesadaran ketuhanan secara agama saja, tetapi bisa kesadaran terhadap makna apa saja yang melampaui batas kemanusiaan.

Menurut Garaudy (1988:34), unsurunsur transedensi ada tiga, yaitu (1) pengakuan tentang ketergantungan manusia kepada Tuhan, (2) ada perbedaan yang mutlak antara Tuhan dan manusia, dan (3) pengakuan akan adanya norma-norma mutlak dari Tuhan yang tidak berasal dari akal manusia. Dalam Islam transendensi itu akan berupa sufisme. Kandungan sufisme, seperti khauf (penuh rasa takut), raja' (sangat berharap), tawakkal (pasrah), qana'ah (menerima pemberian Tuhan), syukur, ihklas, dan sebagainya adalah tema-tema dalam sastra transendental.

Merujuk pada gambaran itulah Kuntowijouyo (1993:288-289) menyebutkan bahwa sastra profetik dapat dihubungkan dengan proses perjalanan umat manusia. Pada hakikatnya, proses perjalanan umat manusia terangkum dalam tiga kategori yang menjadi suatu cita-cita, yakni (1) humanisasi, membina kemanusiaan manusia, (2) liberasi, membangun kemajuan kehidupan sosial, dan (3) transendensi, menciptakan kerinduan kepada hidup yang abadi. Rumusan cita-cita tersebut juga merupakan aspek tujuan yang dicitacitakan oleh sastra profetik (Norhamsyah, 1994:43).

Berdasarkan uraian di atas, menarik untuk dikaji bagaimana profetik sebagai ciri utama fiksi Islmai ditampilkan oleh Habiburrahman El-Syirazi dalam novelnovel yang dihasilkannya, khususnya novel Ketika Cinta Bertasbih. Bagaimanakah realitas profetik tersebut dihubungkan dengan keberadaan manusia modern dengan segala permasalahan yang ada. Salah satunya yakni permasalahan yang menyangkut identitas kedirian manusia baik sebagai individu maupun bagian dari lingkungan sosial. Oleh karena itu, perlu dilakukan penelitian yang mendalam agar dapat mengungkapkan gambaran realitas profetik yang ada dalam novel tersebut.

\section{METODE PENELITIAN}

Sumber data dalam penelitian ini adalah novel dwilogi Ketika Cinta Bertasbih karya Habiburrahman El-Syirazi. Dengan demikian data penelitian ini berupa data yang menyangkut fokus penelitian yaitu realitas profetik dalam kedua novel tersebut. Deskripsi verbal simbol-simbol kebahasaan yang menjelaskan adanya pemaparan realitas profetik yang dijadikan data penelitian.

Data penelitian ini berupa paparan bahasa yang merupakan sebuah wacana atau teks cerita. Pemerolehan data penelitian dilakukan dengan dua cara yaitu pembacaan intensif dan pencatatan. Kegiatan pembacaan intensif dilakukan untuk menemukan realitas profetik dalam novel dwilogi Ketika Cinta Bertasbih. Kegiatan selanjutnya adalah melakukan pencatatan data-data verbal yang berkaitan fokus penelitian. Untuk memudahkan kegiatan analisis, kegiatan pencatatan dilakukan dengan menggunakan kartu-kartu data. Setelah itu, data dicatat dalam kartu data dan dinyatakan sebagai data penelitian. Data diperoleh kemudian dilakukan proses pengkodifikasian data. Pedoman kodifikasi data sebagai berikut.

Sesuai dengan pendekatan penelitian dan masalah yang akan dikaji dalam penelitian ini, teknik analisis data menyangkut dua hal, yaitu (1) aspek struktural dan (2) aspek genetik karya sastra. Kegiatan analisis tahap pertama yaitu rekonstruksi makna dan penafsiran yang diarahkan untuk menangkap gagasan dan pokok 
pikiran yang ada dalam paparan bahasa menyangkut gambaran alienasi manusia. Tahap ini dilakukan untuk menemukan gambaran alienasi manusia yang disampaikan oleh pengarang melalui sarana (struktur) yang terdapat dalam karya sastra.

Kegiatan analisis tahap kedua berkaitan dengan aspek sosio-kultural yang melingkupi penciptaan karya sastra. Aspek-aspek sosio kultural yang dimaksudkan dalam penelitian ini berkaitan dengan keberadaan diri pengarang. Aspek penting dalam analisis ini yaitu mencoba memahami gagasan-gagasan yang ada dalam novel dengan pandangan dunia pengarangnya. Hal itu sesuai dengan konsep dasar pendekatan strukturalisme genetik. Keberadaan karya sastra dipandang sebagai ekspresi pandangan dunia kelompok sosial pengarang dalam merespon kondisi sosial historis yang terjadi dalam masyarakat.

Dalam penelitian ini kesahihan yang digunakan adalah kesahihan yang berorientasi pada data yakni kesahihan semantik. Kesahihan semantis mengukur tingkat kesensitifan suatu teknik terhadap makna-makna simbolik yang relevan dengan konteks tertentu. Untuk kehandalannya digunakan kehandalan berdasarkan kemunculan kembali (reproducibility). Kemunculan kembali menunjukkan seberapa jauh suatu proses dapat diciptakan kembali dalam berbagai lingkungan, pada tempat yang berbeda, menggunakan pengkodean yang berbeda. Teknik kemunculan kembali dalam penelitian ini dilakukan dengan pembacaan dan interpretasi berulang-ulang oleh peneliti. Dari pembacaan intensif dan berulang-ulang diharapkan dapat diperoleh hasil yang memenuhi kriteria kehandalan

\section{HASIL DAN PEMBAHASAN}

Sesuai dengan hasil penelitian di atas, dalam bagian ini dipaparkan pembahasan perihal realitas profetik yang terdapat dalam novel Ketika Cinta Bertasbih karya Habiburrahman El-Shirazy. Pembahasan yang disajikan mencakup tiga aspek, (a) aspek humanisasi, dan (b) aspek liberasi, dan (c) aspek transendensi

\section{Realitas Profetik pada Aspek Human- isasi dan Dehumanisasi}

Dewasa ini diyakini bahwa kehidupan manusia sedang terpecah-pecah sedemikian rupa. Kondisi tersbut terjadi karena berbagai faktor, seperti kemajuan teknologi, pengagungan terhadap ilmu pengetahuan, dan filsafat yang pada gilirannya membawa manusia pada situasi penuh kebingungan dan kegamangan.

Manusia sekarang cenderung terbentuk menjadi manusia-manusia abstrak dan bukan pribadi-pribadi yang utuh, kokoh, dan nyata. Akibat dari semua itu, kemudia terciptalah rasa asing manusia terhadap dirinya sendiri, alam, masyarakat, dan bahkan dengan Tuhannya (Anwar, 2005:67).

Humanisme, yang dapat diterjemahkan sebagai sebuah aliran dalam filsafat, menegaskan bahwa tujuan pokoknya adalah untuk keselamatan, kesejahteraan umat manusia. Humanisme sebagai sebuah istilah merupakan titik temu atau kesepakatan dari beberapa prinsip dasar menyangkut kedirian manusia, baik dari pandangan agama, ilmiah, maupun kemasyarakatan. Humanisme memandang manusia sebagai makhluk yang mulia dan prinsip-prinsip yang disarankan selalu berlandaskan kepada kehendak pemenuhan kebutuhan-kebutuhan pokok yang bias membentuk species manusia (Syariati, 1992:37).

Dalam Islam, konsep humanisme lebih banyak mengacu pada kitab suci AlQuran. Dalam pespektif Islam, walaupun dipahami bahwa tidak ada jarak yang memisahkan manusia dengan Tuhan dalam bentuk "tak terhingga", tetapi tetap ada sempadan pemisah yang sempurna antara Tuhan dan manusia. Sempadan 
pemisah itu salah satunya adalah kenyataan bahwa manusia adalah makhluk yang diciptakan dan Tuhan adalah Sang Pencipta.

Sebagaimana diuraikan di atas, humanisasi kita perlukan, sebab ada tandatanda bahwa masyarakat kita sedang menuju ke arah dehumanisasi. Dehumanisasi ialah objektivasi manusia (teknologis, ekonomis, budaya, massa, negara), agresivitas (kolektif, perorangan, kriminalitas), loneliness (privatisasi, individualisasi), dan spiritual alienation (keterasinga spiritual. Dalam dehumanisasi perilaku manusia lebih dikuasai bawah sadarnya daripada kesadarannya. Dehumanisasi telah menggerogoti masyarakat Indonesia yang tampak dalam beberapa hal, yakni (1) terbentuknya manusia mesin, (2) manusia dan masyarakat massa, dan (3) budaya massa.

Herbert Marcuse, seorang filsuf mazhab Frankfurt, mengemukakan bahwa manusia modern telah kehilangan dimensi spiritualnya. Yang tinggal dari manusia modern hanyalah dimensi material. Oleh sebab itu Marcuse menjuluki manusia modern sebagai manusia satu dimensi (one dimentional man). Manusia menjadi elemen yang mati dalam proses produksi. Modernitas telah memperbudak manusia sekedar menjadi otomat dari proses produksi. (Kuntowijoyo, 1993: 161).

Pandangan-pandangan tentang manusia modern jelas tergambar dalam pada tokoh Eliana dalam novel Ketika Cinta Bertasbih. Eliana digambarkan sebagai pribadi yang telah terjebak pada pusaran modernitas kehidupan. Dia berasal dari keluarga diplomat sehingga memungkinkan dirinya bersentuhan langsung dengan berbagau budaya, utamanya budaya barat. Sebagai seorang yang pernah mengenyam pendidikan barat, ukuran yang digunakan dalam menilai setiap perilaku lebih disandarkan pada rasionalitas dan kelaziman budaya.
Ketika ingin mengucapkan terima kasih kepada Azam (tokoh utama novel ini) Eliana ingin menerapkan kebiasaan yang dianggapnya sudah lazim dalam kehidupan pribadinya, yakni dengan memberi hadih ciuman. Hal itulah yang dianggap oleh Azam sebagai bentuk pengingkaran terhadap kaidah dan norma agama.

Cantik iya. Tapi kalau tidak bisa menjaga aurat, tidak merasa malu. Tidak memakai jilbab, tidak mencintai cara hidup yang agamis, berarti bukan gadis yang aku idamkan (hlm 69)

Dan ia ditawari untuk jadi lelaki kesekian yang berciuman dengannya. Ini jelas bertentanggan dengan apa yang ia jaga selama ini. Yaitu, kesucian. Kesucian jasad, kesucian jiwa, kesucian niat, kesucian pikiran, kesucian hidup, dan kesucian kematian (hlm 71)

Pertentangan antara hiruk pikuk dunia dan ketenangan jiwa, dapat kita lihat juga dalam penampilan latar cerita yang menggambarkan situasi sebuah pasar. Azam adalah seorang mahasiswa yang harus berusaha sekuat tenaga untuk menghidupi dirinya dan bahkan juga untuk kehidupan kedua adiknya di Indonesia. Untuk itu, selama menjalani kuliah di Kairo Mesir, Azam harus membanting tulang agar dapat mencukupi kebutuhan hidupnya dengan berjualan tempe. Dalam rangka menjalankan aktivitasnya inilah Azam senantiasa bersentuhan dengan pasar.

Dalam sebuah esainya Goenawan Mohamad, pernah menggambarkan bahwa pasar merupakan sebuah tempat di mana kesendirian sebenarnya justru hadir, yakni dalam beberapa hal (a) kebersamaan yang semu, (b) perjumpaan yang sementara, dan (c) hanya berlangsung di permukaan. Model sebuah pasar adalah tempat di mana orang di dekat kita adalah pesaing 
kita. Di dalam pasar, rasa iri bukan hal yang salah, rakus bisa jadi bagus, dan keduanya dilembagakan dalam sebuah sistem. (Kalam, No.7, 1996: 110).

Heterogenitas yang ada di pasar bermuara pada satu tujuan: uang/materi. Kondisi semacam itulah yang ingin dikritik Habiburrahman dalam novel ini. Pasar menjadi salah seting tempat dominan dalam novel ini, di samping dunia pesantrean dengan masjid sebagai pusat pusaran aktivitas manusia dis sekitarnya. Masyarakat dalam pusaran pasar adalah masyarakat semu. Kondisi masyarakat satu dimensi. Masyarakat semacam itu telah kehilangan satu hal yang sangat berharga: ketenangan dan ketentraman batin; spiritualitas.

Modernitas, melalui proyek industrialisasinya, di samping telah memberikan berbagai kemudahan bagi manusia, juga telah menjebak manusia dalam budaya pop (mass culture). Budaya massa merupakan akibat dari proses massifikasi. Ini disebabkan dalam sektor budaya terjadi industrialisasi dan komersialisasi. Persis seperti yang diungkapkan oleh Kierkegaard di awal tulisan ini. Manusia modern telah menjelma menjadi manusia massa. Massifikasi dan kolektivisme menjadi hantu-hantu yang memusnahkan ketunggalan kepribadian manusia (Hassan, 1992:28.)

Dalam masyarakat modern, masyarakat komoditas, bagi Baudrilard, dorongan konsumsi bukanlah terutama kenikmatan atau kegunaan, melainkan keinginan untuk mengambil dan memamerkan "nilai tanda" (Kalam, No. 7, 1996: 113). Masifikasi tidak hanya berpengaruh pada dimensi fisik-material saja, tapi juga berdampak pada pembentukan kesadaran massa. seseorang membeli sesuatu bukan karena membutuhkannya, tapi ia menginginkan citra yang sama dengan orang lain. Yang dia beli bukanlah nilai guna, tapi nilai citra (image value).
Kuntowijoyo mengajukan dua cara yang bisa ditempuh untuk mengatasi massifikasi, yaitu dengan (1) privatisasi dan (2) spiritualitas (Subandi, 1997: 55). Kesadaran kolektif, bagi Kunto, selalu tidak mewakili kesadaran pribadi. Kekuatankekuatan yang tak terlawan memaksa kita meninggalkan fitrah. Hanya pribadi yang mempunyai roh. Rohlah yang tidak terikat oleh aktualitas, dan merupakan potensi yang memerdekakan. (DKJ, 1984: 155).

\section{Realitas Profetik pada Aspek Liberasi}

Pada aspek liberasi, salah satu yang ditampilkan dalam novel ini adalah relasi laki-laki dan wanita dalam bingkai kehidupan rumah tangga. Tokoh yang dijadikan sebagai media menampilkan aspek ini yaitu Furqon dan Anna Althafunnisa. Dalam perspektif nilai sosial kemasyarakatan, tokoh Furqon dan Anna menjadi pribadi yang relatif sempurna. Furqon berasal dari keluarga kaya dan terhormat dari Jakarta sedangkan Anna digambarkan sebagai wanita sholehah, anak seorang kyai yang terkenal dan memiliki pondok pesantren di daerah klaten.

Aspek liberasi atau usaha mengembangkan kehidupan sosial yang ditekankan pada masalah ini adalah posisi wanita dalam ikatan pranikah dan setelah pernikahan. Melalui tokoh Anan, pengarang ingin menegaskan bahwa Islam mengajarkan bahwa wanita juga memiliki hak yang seimbang dalam perjanjian suci pernikahan. Salah satu bentuk kesejaran dari posisi wanita, dalam novel ini digambarkan bagaiman Anna mengajukan beberapa persyaratan kepada Furqon sebagai calon suaminya. Persyaratan yang diajukan yaitu (a) setelah menikah akan tetap tinggal dan ingin mengabdi di pesantren, dan (b) selama dirinya masih mampu melaksanakan tugas dan kewajiban sebagai istri dalam batas kewajaran, dia tidak ingin Furqon menikah lagi. Seorang wanita dapat mengajukan per- 
syaratan kepada laki-laki sebelum pelaksanaan pernikahan. Persyaratan tersebut semata-mata ditujukan pada upaya menjaga keselamatan dan kemaslahatan pernikahan dan sama sekali tidak terkait dengan permasalahan harta benda.

“Saya punya syarat yang syarat ini menjadi bagian dari sahnya akad nikah. Artinya farji saya halal di antaranya jika syarat saya ini dipenuhi oleh Mas Furqan." Kata Anna di majelis musyawarah itu.

"Apa itu syaratnya?" Tanya Furqan.

"Pertama, setelah menikah saya harus tinggal di sini. Saya tidak mau tinggal selain di lingkungan pesantren ini. Kedua, saya mau dinikah dengan syarat selama saya hidup dan saya masih bisa menunaikan kewajiban saya sebagai isteri Mas Furqan tidak boleh menikah dengan perempuan lain!" Dengan tegas Anna menjelaskan syarat yang diinginkannya.

Kalimat yang diucapkan itu cukup membuat kaget Furqan dan keluarganya. "Apa syarat-syarat itu tidak mengada-ada?" Kata Pak Andi Hasan, ayah Furqan. "Tidak. Sama sekali tidak. Para ulama sudah membahasnya panjang lebar. Dan syarat yang saya ajukan ini sah dan boleh." Jawab Anna. Pak Kiai Lutfi diam saja. Dia percaya bahwa putrinya pasti bisa memperjuangkan apa yang menjadi maslahat bagi masa depannya. "Maaf, untuk syarat pertama saya rasa tidak ada masalah. Itu sah dan boleh-boleh saja. Tapi untuk syarat kedua, apa tidak berarti kamu mengharamkan poligami?" Gugat Furqan.

"Mohon Mas Furqan melihat dan meneliti dengan seksama, dibagian mana dan di teks mana saya mengharamkan poligami yang dihalalkan oleh Al Quran. Tidak, sama sekali saya tidak mengharamkan. Kalau Mas Furqan menikah dengan selain saya,
Mas mau menikahi langsung empat wanita juga saya tak ada masalah. Itu hak Mas Furqan. Syarat itu sama dengan syarat misalnya saya minta setelah menikah Mas Furqan tidak makan Jengkol, karena saya tidak suka. Jengkol itu bau. Baunya saya tidak suka. Apa itu berarti saya mengharamkan Jengkol? Saya meminta syarat untuk sesuatu yang menurut saya bermanfaat bagi saya dan anakanak saya. Dan dengan syarat ini Mas Furqan sama sekali tidak dirugikan, sebab saya mengatakan tidak boleh menikah dengan perempuan lain selama saya hidup dan saya masih bisa menunaikan kewajiban saya sebagai isteri. Kalau saya sakit menahun dan tidak bisa menunaikan kewajiban saya ya silakan menikah. Syarat yang seperti ini dibolehkan oleh ulama." Anna beragumentasi membela syarat yang diajukannya.

"Maaf saya belum pernah membaca ada ulama membolehkan syarat seperti itu." Tukas Furqan.

"Baiklah. Tunggu sebentar!" Kata Anna. Gadis itu masuk ke kamarnya dan mengambil sebuah kitab. Pada halaman yang ditandainya ia membukanya dan langsung menyodorkannya pada Furqan,

“Ini juz 7 dari kitab Al Mughni karya Ibnu Qudamah, silakan baca di halaman 93!"

Furqan menerima kitab itu lalu membaca pada bagian yang diberi garis tipis dengan pensil oleh Anna. Saat membaca kening Furqan berkerut. Ia lalu mendesah. Ia diam sesaat. Wajahnya agak bingung.

Hal yang patut dicatat pada konteks kekinian, gambaran dalam novel tersebut menunjukkan bahwa seorang wanita mempunyai kedudukan yang penting dalam ikatan perkawinan. Artinya, sejak awal ketika akan dilaksanakan akad nikah 
sebagai pertanda berdirinya bangunan rumah tangga, dalam hal-hal prinsip dan tidak melanggar syariah, seorang wanita juga dapat mengambil peran dalam rangka pengabdian penuh pada keberlangsungan rumah tangga.

\section{Realitas Profetik pada Aspek Transen- densi}

Bagian penting lainnya pada realitas profetik yakni menyangkut aspek transendensi. Sebagaimana telah diuraikan pada bagian kajian teori, salah satu tujuan sastra profetik adalah memusatkan perhatian dan penekanannnya pada aspek transendensi. Inti dari aspek transendensi adalah menciptakan kerinduan kepada hidup yang abadi, hidup dan kehidupan itu sendiri.

Cita-cita transendensi atau menciptakan kerinduan kepada hidup yang abadi ini jelas berintikan kepada "hidup" itu sendiri, yakni kepada keinginan akan kesempurnaan hidup. Kesempurnaan hidup itu lahir dari pertemuan atau garis singgung antara kutub vertika dan kutub horizontal, antara cita-cita dan kenyataan, antara jiwa dan pikiran, antara akal-kalbu dan akal pikiran.

Konsekuensi logis dari logika di atas adalah munculnya kesadaran bahkan rasa ketergantungan kepada Tuhan. Segala hal yang dilihat, dirasakan, dihadapi, dialami, harus senantiasa dikembalikan pada keberadaan Tuhan. Bahkan dengan kalimat yang sederhana dapat dirumuskan, jika kita melakukan sesuatu dan kita tidak melihat "kehadiran" Tuhan, maka yakinlah bahwa apa yang kita lakukan itu hanya kesia-siaan.

Kesadaran ke-Tuhan-an itulah yang ditampilkan oleh pengarang melalui tokoh Azam. Bagi Azam, apapun yang ada di hadapannya selalu direlasikan dengan dimensi vertikal.

Tak terlintas sedikit pun bahwa senja yang indah yang mereka lalui itu akan menjadi saksi sejarah bagi mereka kelak. Ya, kelak ketika masa muda mereka harus dipertanggungawabkan di hadapan Sang Pencipta Cinta. Dan jatuh cinta mereka pun harus dipertanggungjawabkan kepada-Nya, di hadapan pengadilan Dzat Yang Maha Adil, yang tidak ada sedikit pun kezaliman dan ketidakadilan di sana (hlm 34)

Laut itu begitu luas dan kapal itu begitu kecil. Padahal di dalam kapal itu mungkin ada ratusan manusia. Ia jadi berpikir, alangkah kecilnya manusia. Dan alangkah Maha Penyayangnya Tuhan menjinakkan lautan sedemikian luas supaya tenang dilalui kapalkapal berisi manusia.

Tuhan masih saja menunjukkan kasih sayang-Nya. Ia teringat firman-Nya yang indah: Tidakkah engkau memperhatikan bahwa sesungguhnya kapal itu berlayar di laut dengan nikmat Allah, agar diperlihatkan-Nya kepadamu sebagian dari tanda-tanda kebesaran-Nya.... (QS Luqman:31)

Ya, alam bertasbih dengan keindahannya. Alam bertasbih dengan keteraturannya. Alam bertasbih dengan pesonanya. Segala keindahan, keteraturan, dan pesona alam bertasbih menjelaskan keagungan Sang Pencipatnya

Siang, malam, senja, dan pagi bertasbih. Matahari, udara, laut, ombak, dan pasir bertasbih. Semua benda yang ada di alam semesta ini bertasbih, menyucikan asma Allah. Semua telah tahu bagaimana cara melakukan shalat dan tasbih.

Berdasarkan cara berpikir dalam Islam, yang senantiasa berpusat kepada Tuhan dan Al-Quran, nilai manusia yang 
sedalam-dalamnya, dan sesungguhnya akan ditentukan oleh hubungannya dengan Allah SWT, Dzat yang mutlak, dalam rangka hari akhir yang bersifat langgeng dan kekal. Dalam perspektif ini, Tuhan adalah satu-satunya referensi pokok dan mendasar, sebab Tuhan merupakan puncak dan sekaligus tujuan dari sejarah nasib manusia.

Manusia menurut Islam merupakan makluk merdeka. Artinya, manusia adalah makhluk yang bebas memilih sesuatu dalam hidupnya. Hal itu menjadi suatu penegasan, bahwa jika Tuhan akan memaksakan kehendak-Nya atas manusia, tentulah Tuhan tidak akan membiarkan seorang manusia memilih jalan yang sesat (QS, 7:168).

Kemungkinan lain dari pernyataan di atas adalah bahwa jika manusia mencoba mengingkari kemerdekaannya, tentulah manusia tersebut dapat dengan mudah mengingkari tanggung jawabnya. Padahal, Tuhan telah menunjukkan jalan kepada manusia dengan jalan mengajak perasaan dan pikirannya sehingga manusia mampu menjadi makhluk yang bertanggung jawab terhadap nasibnya sendiri. Pada konteks inilah letak kebebasan manusia yang sesungguhnya. Kebebasan (dalam arti bebas untuk bukan bebas dari) yang timbul akibat ketidaktahuannya mengenai kehidupan di masa yang akan datang. Kehidupan masa datang itu sendiri secara hakiki telah disediakan oleh Tuhan untuk diri manusia. Dengan ketidaktahuannya pada masa datang itulah memungkinkan penafsiran makna bahwa tindakantindakan yang timbul merupakan hasil kemauan dan keputusan manusia yang merdeka dan bertanggung jawab.

\section{SIMPULAN}

Berdasarkan penelitian yang dilakukan dapat disimpulkan beberapa hal sebagai berikut. Pertama, realitas profetik pada asepk humanisai mencakup aspek (a) manusia yang merasa telah menjadi
Tuhan, (b)manusia yang merasa telah menyerahkan nasibnya kepada Tuhan (Tuhan Manusia), dan (c) budaya masa dan manusia massa. Kedua, realitas profetik pada aspek liberasi meliputi aspek, (a) relasi kehidupan spiritual dan realitas sosial, (b) relasi iman, ilmu, dan amal, dan (c) relasi kehidupan berkeluarga, bertetangga, dan bermasyarakat. Ketiga, realitas profetik pada aspek transendensi melipuri aspek (a) pengakuan tentang ketergantungan manusia pada Tuhan, (b) pengakuan tentang adanya perbedaan mutlak antara Tuhan dan manusia, dan (c) pengakuan akan adanya norma mutlak dari Tuhan yang tidak berasal dari akal manusia

Penelitian yang mengungkapkan tentang realitas profetik dalam novel Ketika Cinta Bertasbih karya Habiburraham El-Shyrazy ini masih terbatas pada kajian yang bersifat struktural semiotik. Oleh karena itu masih sangat terbuka kemungkinan untuk melakukan kajian lebih lanjut, khususnya diarahkan pada masyarakat pembaca. Kajian dapat dilakukan dengan memanfaatkan pendekatan resepsi sastra. Dengan demikian akan diketahui tanggapan masyarakat terhadap realitas profetik yang ditampilkan dalam novel tersebut.

\section{UCAPAN TERIMA KASIH}

Artikel ini disarikan dari hasil penelitian mandiri yang dilaksanakan di Fakultas Bahasa dan Seni dengan anggaran dana DIPA FBS UNY tahun 2007. Ucapan terrima kasih kami sampaikan kepada DPP Penelitian FBS UNY yang telah memfasilitasi penelitian ini hingga selesai. Ucapan terima kasih juga kami sampaikan kepada reviewer yang telah mengoreksi dan memberi masukan terhadap artikel ini

\section{DAFTAR PUSTAKA}

Anwar, M.Wan. 2005. Kuntowijoyo, Menjejak Bumi Menjangkau Langit.

Realitas Profetik dalam Novel Dwilogi Ketika Cinta Bertasbih Karya Habiburrahman El-Shirazy 
Dalam Majalah Satra Horison. Edisi XXXIX/5/2005, Mei 2005

Garaudy, R. 1988. Janji-janji Islam. Jakarta: Bulan Bintang

Hadi WM, Abdul. 1986. "Semangat Profetik dalam Sastra Sufi dan Jejaknya dalam Sastra Indonesia Modern". Jakarta: Horison/XXII/1986

Hadi WM, Abdul. 1996. Tasawuf yang Tertindas: Kajian Hermenutik terhadap Karya-karya Hamzah Fanzuri. Jakarta: Pustaka Firdaus.

Hadi WM, Abdul. 1999. Kembali ke Akar Kembali ke Sumber. Jakarta: Pustaka Firdaus.

Hadi WM, Abdul. 2004. Hermeneutika, Estetika, dan Religiusitas. Yogyakarta: Mahatari.

Herfanda, Ahmadun Yosie. 2007. “Genre Fiksi Islami dalam Sastra Indonesia Mutakhir". Republika, 4 Maret 2007.

Kuntowijoyo. 2005. Budaya dan Masyarakat. Yogyakarta: Tiara Wacana.
Kuntowijoyo. 2006. Maklumat Sastra Profetik. Yogyakarta: Grafindo Litera Media

Malay, Afnan. 1988. “Budaya Profetik dan Keterasingan Umat”. Jakarta: Majalah Amanah.

Mangunwijaya, Y.B. 1988. Sastra dan Religiositas. Yogyakarta: Penerbit Kanisius.

Mashuri. 2003. "Menggagas Sastra Religius yang Berkualitas". http://islamlib .com/id. 21 Agustus 2003

Norhamsyah. 1994. "Nuansa ProfetikDialektis dalam Karya Prosa Kuntowijoyo". Skripsi tidak diterbitkan. Fakultas Sastra Universitas Gadjah Mada

Syari'ati, A. Tanpa tahun. Humanisme: Antara Islam dan Mazhab Barat. Terjemahan Afif Muhammad. 2003. Bandung: Penerbit Mizan. 